Journal of Science Education Research

Journal homepage: www.journal.uny.ac.id/jser

JSER

\title{
Utilization of indonesian megabiodiversity for integrated science learning with nationalism values to develop concepts understanding and soft security among students of border areas
}

\author{
Sukardiyono $^{1^{*}}$, Dadan Rosana ${ }^{2}$ \\ ${ }^{1}$ Study Program of Physics Education, Faculty of Mathematics and Natural Sciences, Universitas Negeri Yogyakarta \\ ${ }^{2}$ Study Program of Science Education, Faculty of Mathematics and Natural Sciences, Universitas Negeri Yogyakarta \\ Corresponding Author. Email: sukardiyono@uny.ac.id
}

\author{
Keywords: \\ subject specific \\ pedagogic, \\ megabiodiversity, \\ soft security, \\ science learning \\ outcomes
}

\begin{abstract}
This research aimed at (1) producing Subject Specific Pedagogic (SSP) of integrated science learning with nationalism values by utilizing Indonesian megabiodiversity which is valid and practical for the students of border areas, (2) obtaining empirical test results on the effectiveness of SSP integrated science learning with nationalism values by utilizing Indonesian megabiodiversity to improve the quality of students' learning outcomes and soft security in border area. The SSP was prepared through a research design referring to "Prototypal Studies" as put forward by Akker (1999) and Plomp (2001). The important thing that needs to be considered in the development research is the quality of the produced learning tools (product). Plomp (2001) has pointed out the product quality criteria, namely: valid (reflects state-of-the-art knowledge and internal consistency), added value, practical, and effective. This research is intended to solve the problems of junior high schools in the region of (1) Atambua, Belu Regency, East Nusa Tenggara Province, and (2) Entikong, Sanggau Regency, West Kalimantan Province. The reserach results showed that SSP science learning integrating Indonesian megabiodiversity utilization with nationalism values was valid, practical and effective to develop concepts understanding and soft security among students in border areas schools.
\end{abstract}

C2018 JSER. Yogyakarta State University

\section{INTRODUCTION}

As a multicultural nation surounded by geographical conditions with thousands of islands, Indonesian peoples requires a bond that is able to "unify themselves" and "their life orientation". It must be realized since an early age through a structured and purposeful formal education without eliminating its diversity. Morality and resilience of community culture is the key factor to maintain the state integrity. Therefore, these two domains must obtain a special attention in every movement of the national development (Dantes, 2012).
To strengthen national defense, it is not just rely on hard security, especially human rights appreciation and globalization ethos put forward by the United Nations. It urges some appropriate solutions to support national security defense and (Lasmawan, 2014). One of visible alternatives is "building soft security" through formal education context. The relevant learning concept to foster national security is "a comprehensive approach to moral values and character education" as presented in the following chart (Lickona, 1991: 69). 


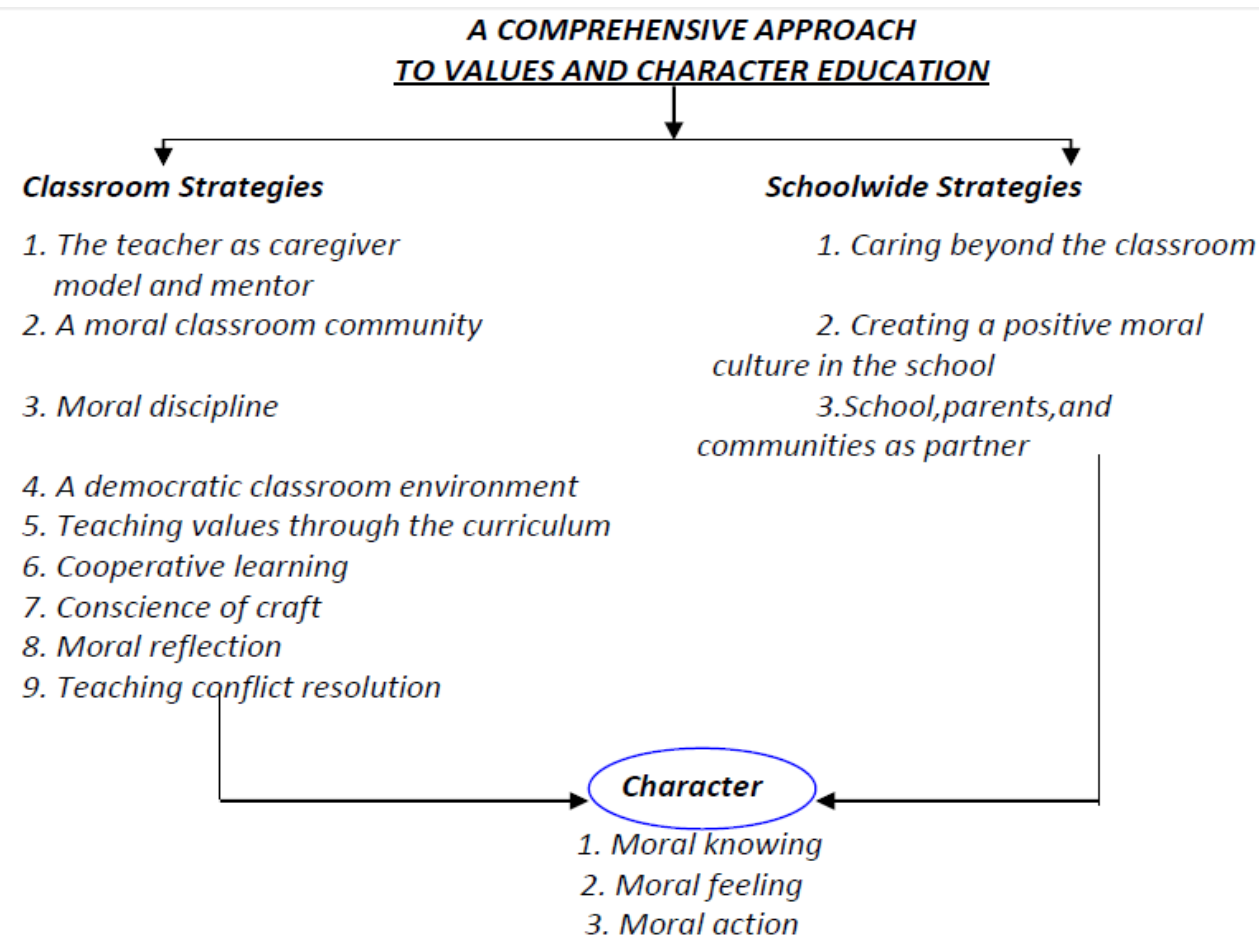

Figure 1. A comprehensive approach to moral values and character education

The 2013 curriculum has tried to develop religious attitudes (Core Competencies of 1) and social attitudes (Core Competencies of 2). However, it is not implemented properly yet, because there is a separation between scientific field and character education. Those two core competencies has not explicitly developed national character values, such as nationalism which can support the grow of soft security. The current national education curriculum still has greater emphasis on "cognitive enhancement" while "mental-moral integrity and development" has not been optimally developed. Responfing to this, research on the development and implementation of Subject Specific Pedagogic (SSP) integrated science learning with nationalism values by utilizing Indonesian megabiodiversity is expected to produce outcomes based on the field being studied. The design of national soft security model by utilizing Indonesian megabiodiversity can substantively become a "role model" of the education management strategies, especially in the border areas.

Indonesia as one of Megabiodiversity countries in the world is blessed with various biodiversity and the high level of endemism, ecological uniqueness, and organisms in a very high geographic structure. Those can be potentially used as one of the basic capital of sustainable development. To bring it into reality, the educational institutions in the Indonesian border region must be optimized. It can be done by utilizing the megabiodiversity as a source of natural science learning as well as growing a sense of pride by having plentiful natural resources in the archipelago. The following strategy is to develop soft security among students in the border region.

This study is to respond "deep apprehension " and "empirical facts" of policing the moral abrasion of nationality among the community, especially among society in border areas, which can be easily provoked by neighboring countries and prone to conflict. It is done as an anticipation action by improving the quality of educational processes and products as strategic intermediate targets. This research aimed at (1) producing Subject Specific Pedagogic (SSP) integrated science learning with nationalism values by utilizing Indonesian megabiodiversity which is valid and practical for the students of border areas, (2) obtaining empirical test results on the effectiveness of SSP integrated science learning with nationalism values by utilizing Indonesian megabiodiversity to improve the quality of students' learning outcomes and soft security in border area.

\section{METHOD}

The main focus of this research is Subject Specific Pedagogic (SSP) of integrated science learning with nationalism values by utilizing Indonesian megabiodiversity which is valid and 
practical for the students of border areas. It means the main goal of the study is to produce a new spectrum of sciences education integrating with the nationalism values for potential citizens (junior high school students). Based on these rationales, this study was prepared through a research design referring to "Prototypal Studies" as put forward by Akker (1999) and Plomp (2001). The important thing that needs to be considered in the development research is the quality of the produced learning tools (product). Generally, Plomp (2001) states that the implementation of development research includes three phases: the front-end analysis, the prototyping phase, and the assessment phase or summative evaluation. Related to the reserach activity of this research is developing Subject Specific Pedagogic (SSP) of integrated science learning with nationalism values by utilizing Indonesian megabiodiversity. The mechanism for the research implementation can be described in detail as follows.

Table 1. Assessment Implementation Method

\begin{tabular}{|c|c|c|c|}
\hline Activities & Purposes & Methods & Results/Outcomes \\
\hline $\begin{array}{l}\text { Front-end } \\
\text { Analysis: } \\
\text { Literature } \\
\text { review }\end{array}$ & $\begin{array}{l}\text { 1. Identifying educational } \\
\text { competencies of state } \\
\text { defense for junior high } \\
\text { schools according to the } \\
2013 \text { curriculum } \\
\text { 2. Identifying learning } \\
\text { resources, learning models, } \\
\text { assessment models and } \\
\text { tools, and follow-up } \\
\text { education for state defense } \\
\text { of junior high schools } \\
\text { 3. Analyzing natural science } \\
\text { learning based on the } \\
\text { character of nationalism }\end{array}$ & Literature review & $\begin{array}{l}\text { 1. Basic competencies, } \\
\text { learning outcomes, and } \\
\text { indicators of natural } \\
\text { science learning outcomes } \\
\text { based on the nationalism } \\
\text { character for junior high } \\
\text { school that will be } \\
\text { developed } \\
\text { 2. The design of personal } \\
\text { competence, social and } \\
\text { intellectual competence of } \\
\text { students in natural science } \\
\text { based on the nationalism } \\
\text { character }\end{array}$ \\
\hline Field Study & $\begin{array}{l}\text { Identifying } \\
\text { 1. students Characteristics of } \\
\text { 2. Didactic phenomenon } \\
\text { 3. Teacher characteristics } \\
\text { 4. Student learning needs } \\
\text { 5. Social environment of } \\
\text { schools/students }\end{array}$ & $\begin{array}{l}\text { 1. Questionnaire } \\
\text { 2. Interview }\end{array}$ & $\begin{array}{l}\text { 1. Actual social problems } \\
\text { 2. Students } \\
\text { Characteristics } \\
\text { 3. Teacher characteristics } \\
\text { 4. Needs and student } \\
\text { learning environment }\end{array}$ \\
\hline $\begin{array}{l}\text { Expert } \\
\text { Judgment }\end{array}$ & $\begin{array}{l}\text { Data analysis of literature } \\
\text { study results and field } \\
\text { studies }\end{array}$ & $\begin{array}{l}\text { Panel Group } \\
\text { Discussion }\end{array}$ & $\begin{array}{l}\text { 5. blueprint about the new } \\
\text { spectrum of national soft } \\
\text { security for junior high } \\
\text { school students }\end{array}$ \\
\hline Verifikasi & Verifying the blueprint & $\begin{array}{l}\text { Seminar (about } \\
169 \text { persons) }\end{array}$ & $\begin{array}{l}\text { 5. Draft the design of the } \\
\text { model and the national soft } \\
\text { security tols for junior high } \\
\text { school students. }\end{array}$ \\
\hline $\begin{array}{l}\text { Soft security } \\
\text { development } \\
\text { phase for } \\
\text { junior high } \\
\text { school } \\
\text { students and } \\
\text { SSP }\end{array}$ & $\begin{array}{l}\text { Developing a design of } \\
\text { soft security management } \\
\text { models for junior high } \\
\text { school students } \\
\text { as well as the relevant SSP }\end{array}$ & Lab work & $\begin{array}{l}\text { The design of the national soft } \\
\text { security model for junior high } \\
\text { school students as well as the } \\
\text { relevant SSP. (Draft I) }\end{array}$ \\
\hline $\begin{array}{l}\text { Expert } \\
\text { validation }\end{array}$ & $\begin{array}{l}\text { Test the suitability of the model } \\
\text { with student characteristics, } \\
\text { truth of the concept, conformity } \\
\text { with the } 2006 \text { curriculum, } \\
\text { process approach, and legibility }\end{array}$ & Discussion & $\begin{array}{l}\text { The design of the national soft } \\
\text { security model for junior high } \\
\text { school students that is tested } \\
\text { through expert validation (expert } \\
\text { judgment) }\end{array}$ \\
\hline
\end{tabular}


Sukardiyono, Dadan Rosana/ JSER 2018, 2(2), 59

\begin{tabular}{|c|c|c|c|}
\hline $\begin{array}{l}\text { Revising and } \\
\text { re-formulateing } 1 \\
\text { the models and } 1 \\
\text { the learning } \\
\text { tools }\end{array}$ & $\begin{array}{l}\text { producing the design of the } \\
\text { national soft security model for } \\
\text { high quality, valid junior high } \\
\text { school students }\end{array}$ & Lab work & $\begin{array}{l}\text { The design of the national soft } \\
\text { security model for junior high } \\
\text { school students which is } \\
\text { qualified, valid and practical } \\
\text { (second Draft) }\end{array}$ \\
\hline $\begin{array}{l}\text { Initial Model } \\
\text { and SSP trial } \\
\text { (for some units } \\
\text { of material) }\end{array}$ & $\begin{array}{l}\text { The design of the national soft } \\
\text { security model for junior high } \\
\text { school students which is } \\
\text { qualified, valid and practical } \\
\text { (formative evaluation) }\end{array}$ & Case study & $\begin{array}{l}\text { The design of the national soft } \\
\text { security management model } \\
\text { which is qualified, valid and } \\
\text { practical for junior high school } \\
\text { students }\end{array}$ \\
\hline $\begin{array}{l}\text { Revise the } \\
\text { design of soft } \\
\text { security models } \\
\text { for quality } \\
\text { junior high } \\
\text { school students }\end{array}$ & $\begin{array}{l}\text { Producing the national soft } \\
\text { security management model for } \\
\text { junior high school students } \\
\text { which is qualified, valid and } \\
\text { practical }\end{array}$ & Lab work & $\begin{array}{l}\text { The design of the national soft } \\
\text { security management model } \\
\text { which is qualified, valid and } \\
\text { practical for junior high school } \\
\text { students. (Third Draft) }\end{array}$ \\
\hline $\begin{array}{l}\text { Design Trial } \\
\text { of a soft } \\
\text { security } \\
\text { model for } \\
\text { junior high } \\
\text { school } \\
\text { students }\end{array}$ & $\begin{array}{l}\text { The design of the national soft } \\
\text { security management model for } \\
\text { junior high school students } \\
\text { which is qualified, valid and } \\
\text { practical (formative evaluation) }\end{array}$ & Case study & $\begin{array}{l}\text { The design of the national soft } \\
\text { security management model } \\
\text { which is qualified, valid and } \\
\text { practical for junior high school } \\
\text { students }\end{array}$ \\
\hline $\begin{array}{l}\text { Revise the } \\
\text { design of the } \\
\text { soft security } \\
\text { management } \\
\text { model for junior } \\
\text { high school } \\
\text { students }\end{array}$ & $\begin{array}{l}\text { The design of the national } \\
\text { soft security management } \\
\text { model for junior high } \\
\text { school students which is } \\
\text { qualified, valid and } \\
\text { practical (formative } \\
\text { evaluation I) }\end{array}$ & Lab work & $\begin{array}{l}\text { The design of the national soft } \\
\text { security management model } \\
\text { which is qualified, valid and } \\
\text { practical for junior high school } \\
\text { students } \\
\text { (Draft IV) }\end{array}$ \\
\hline $\begin{array}{l}\text { Second trial of } \\
\text { the Model of } \\
\text { the national soft } \\
\text { security } \\
\text { management for } \\
\text { junior high } \\
\text { school students }\end{array}$ & $\begin{array}{l}\text { Developing the design of } \\
\text { national soft security } \\
\text { management model which } \\
\text { is qualified, valid and } \\
\text { practical for junior high } \\
\text { school students (formative } \\
\text { evaluation } \\
\text { II) }\end{array}$ & Case study & $\begin{array}{l}\text { The national soft security } \\
\text { management model which is } \\
\text { qualified, valid and practical } \\
\text { for junior high school students }\end{array}$ \\
\hline $\begin{array}{l}\text { Analyze the } \\
\text { results of } \\
\text { second trial }\end{array}$ & $\begin{array}{l}\text { Reviewing the national } \\
\text { soft security model for } \\
\text { junior high school students } \\
\text { which is qualified, valid } \\
\text { and practical }\end{array}$ & Lab work & $\begin{array}{l}\text { The national soft security } \\
\text { management model which is } \\
\text { qualified, valid and practical } \\
\text { for junior high school students }\end{array}$ \\
\hline $\begin{array}{l}\text { Formulating a } \\
\text { soft security } \\
\text { model for junior } \\
\text { high school } \\
\text { students }\end{array}$ & $\begin{array}{l}\text { Enhancing the national } \\
\text { soft security management } \\
\text { model for junior high } \\
\text { school students }\end{array}$ & Lab work & $\begin{array}{l}\text { The national soft security } \\
\text { management model which is } \\
\text { qualified, valid and practical } \\
\text { for junior high school students }\end{array}$ \\
\hline
\end{tabular}




\section{RESULT}

The soft security development model through the creation of Subject Specific Pedagogic (SSP) of integrated science learning with nationalism values by utilizing Indonesian megabiodiversity was conducted in the junior high schools in the area of Alas Entikong and Atambua. The research and development procedure was divided into four stages, namely (1) define, (2) design, (3) develop, and (4) disseminate.

In the development stage, a model feasibility test as carried out through expert judgment and practicality testing by the lecturers of the sciences education program. The feasibility test was to collect the evaluation and reflection results as a consideration to improving the model and the tools so that it can be used to develop soft security and nationalism character of junior high school students. The model and device were then tested in some limited and wide range of trial. The produced model tools included: (1) subject specific pedagogic (SSP) learning package that integrates the utilization of Indonesian biodiversity and the nationalism character, (2) Lessons Plan for science learning that integrates the utilization of Indonesian biodiversity and nationalism character, (3) Worksheet of learning activities, and (4) assessment of soft security evaluation for junior high school students.

\section{Validation Subject Specific Pedagogic (SSP) which integrates the utilization of Indonesian biodiversity and the nationalism character}

The development results of soft security-based subject specific pedagogic (SSP) were validated through expert judgment which was divided into 6 assessment components, namely; (1) sylabus, (2) lessons plan, (3) worksheet, (4) media, and (5) assessment. Each component employed the scoring aspect Likert scale $(0-4)$. The validation results of each SSP component in the form of mean scores were then converted into scores. The results of the SSP component validation are presented in table 3 and figure 3 below.

Tabel 3. Validation of subject specific pedagogic (SSP) component

\begin{tabular}{lccccc}
\hline & Sylabus & Lessons Plan & Worksheet & Media & Assessment \\
\hline Expert 1 & 3,73 & 3,84 & 3,51 & 3,50 & 3,44 \\
\hline Expert 2 & 3,65 & 3,68 & 3,43 & 3,48 & 3,72 \\
\hline Average & 3,69 & 3,76 & 3,47 & 3,49 & 3,58 \\
\hline Category & Good & Very Good & Good & Good & Good \\
\hline
\end{tabular}

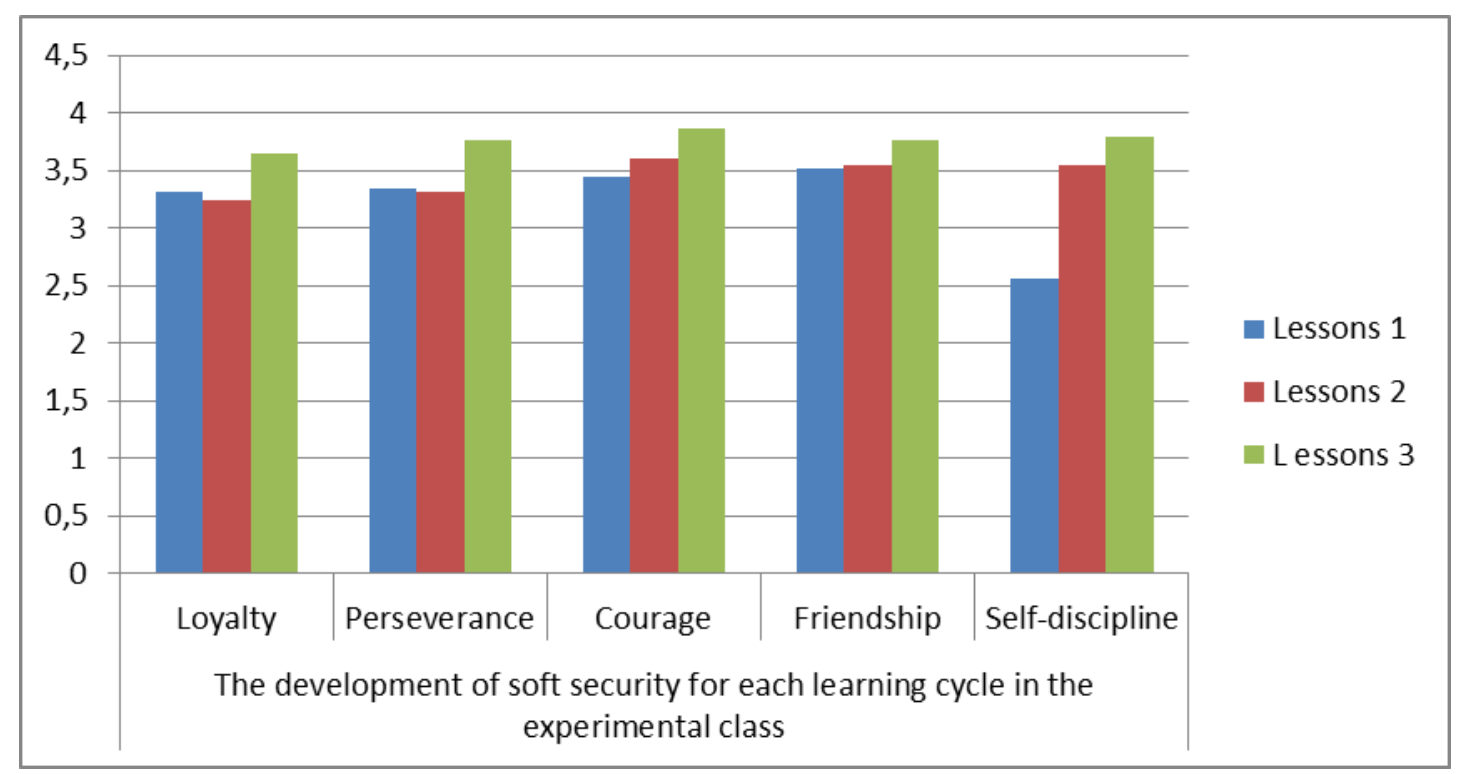

Figure 3. Graph of expert judgment result on subject specific pedagogic 
The SSP validation results indicated that the two learning experts categorizes Lessons Plan component as "Very Good" and "Good" category for other four components (sylabus, worksheet, media and assessment). The results of this validation showed that the subject specific pedagogic (SSP) of integrated science learning has been appropriate to be used in learning process.

\section{SSP Practical Test Results}

The development results of the lesson plan were tested with trials in two partnership schools involving its Natural Science teachers Is. The SSP components tested for preactivity are divided into 6 assessment components, namely; (1) Sylabus, (2) Lessons plan, (3) worksheet,
(4) media, and (5) assessment. Each component has a scoring aspect using Likert scal $(0-4)$. The results of the trial for each SSP component in the form of mean scores were converted into values. The results of the SSP component validation are presented in table 4 and 4 below.

The results of the SSP practicality test showed that both teachers gave "very good" category for three components (Sylabus, Lessons Plan, and Media) and "Good" category for the other two components (worksheet and assessment). The results of this validation indicated that subject specific pedagogic (SSP) science learning that integrates the use of Indonesian biodiversity and the nationalism character has fulfilled the practicality aspects and considered appropriate to be used in learning process.

Table 4. SSP Practicality Test Results in Natural Science Learning

\begin{tabular}{lccccc}
\hline & Sylabus & Lessons Plan & Worksheet & Media & Assessment \\
\hline Teacher 1 & 3,78 & 3,84 & 3,56 & 3,85 & 3,46 \\
\hline Teacher 2 & 3,76 & 3,68 & 3,76 & 3,65 & 3,72 \\
\hline Average & 3,77 & 3,76 & 3,66 & 3,75 & 3,59 \\
\hline Category & Very Good & Very Good & Good & Very Good & Good \\
\hline
\end{tabular}

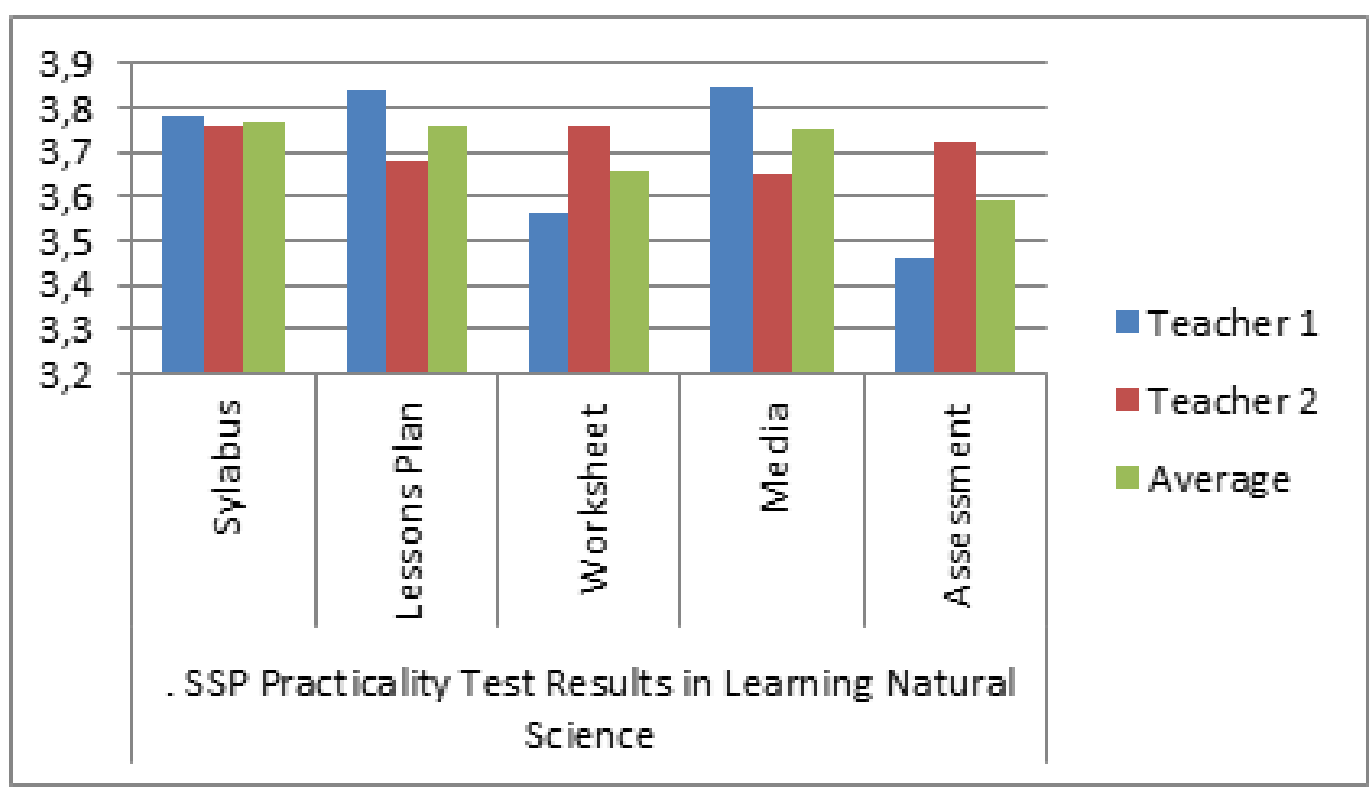

Figure 4. SSP Practicality Test Results in Natural Science Learning 


\section{Discussion results on the limited trial}

\subsection{Soft Security Assessment Results}

The limited field trials were carried out in the junior high schools in the area of Alas Entikong and Atambua. The research sample consisted of two classes respectively, namely the control and the experimental class. The assessment process was done in each stage of learning of the experimental class using questionnaires and observation sheets. Indicators of soft security were divided into six components, namely; (1) loyalty, (2) perseverance, (3) courage, (4) friendship, (5) self-discipline, and (6) responsibility of which each component with its own assessment indicator. Validation results for each soft security component in the form of mean scores were then converted into values. The following is the results of soft security component validation in table 5 and figure 5.

The soft security measurement was carried out through observation during the learning process as well as questionnaire distribution. The result showed an escalation of the mean score towards students' soft security from the first into third meeting. It indicated that SSP natural science by utilizing megabiodiversity can increase students' soft security. Moreover, the soft security indicators that can be measured for this study including; (1) Loyalty ("Good" category), (2) Perseverance ("Good"category), (3) Courage ("Good"category), (4) Friendship ("Good”category), (5) Self-discipline ("Good"category), and (6) Responsibility (“Good"category).

Table 5. The development of soft security for each learning cycle in the experimental class

\begin{tabular}{lcccccccc}
\hline & Loyalty & Perseverance & Courage & Friendship & $\begin{array}{c}\text { Self- } \\
\text { discipline }\end{array}$ & Responsibility & A & C \\
\hline L 1 & 3,32 & 3,34 & 3,44 & 3,52 & 2,56 & 2,60 & 3,14 & G \\
\hline L 2 & 3,24 & 3,31 & 3,60 & 3,55 & 3,55 & 3,62 & 3,45 & G \\
\hline L 3 & 3,65 & 3,76 & 3,86 & 3,76 & 3,79 & 3,76 & 3,77 & V \\
\hline A & 3,40 & 3,47 & 3,63 & 3,61 & 3,30 & 3,33 & & \\
\hline C & G & G & G & G & G & G & &
\end{tabular}

Explanation : $\mathrm{L}=$ Lessons, $\mathrm{A}=$ Average, $\mathrm{C}=$ Category, $\mathrm{G}=$ Good, $\mathrm{V}=$ Very Good

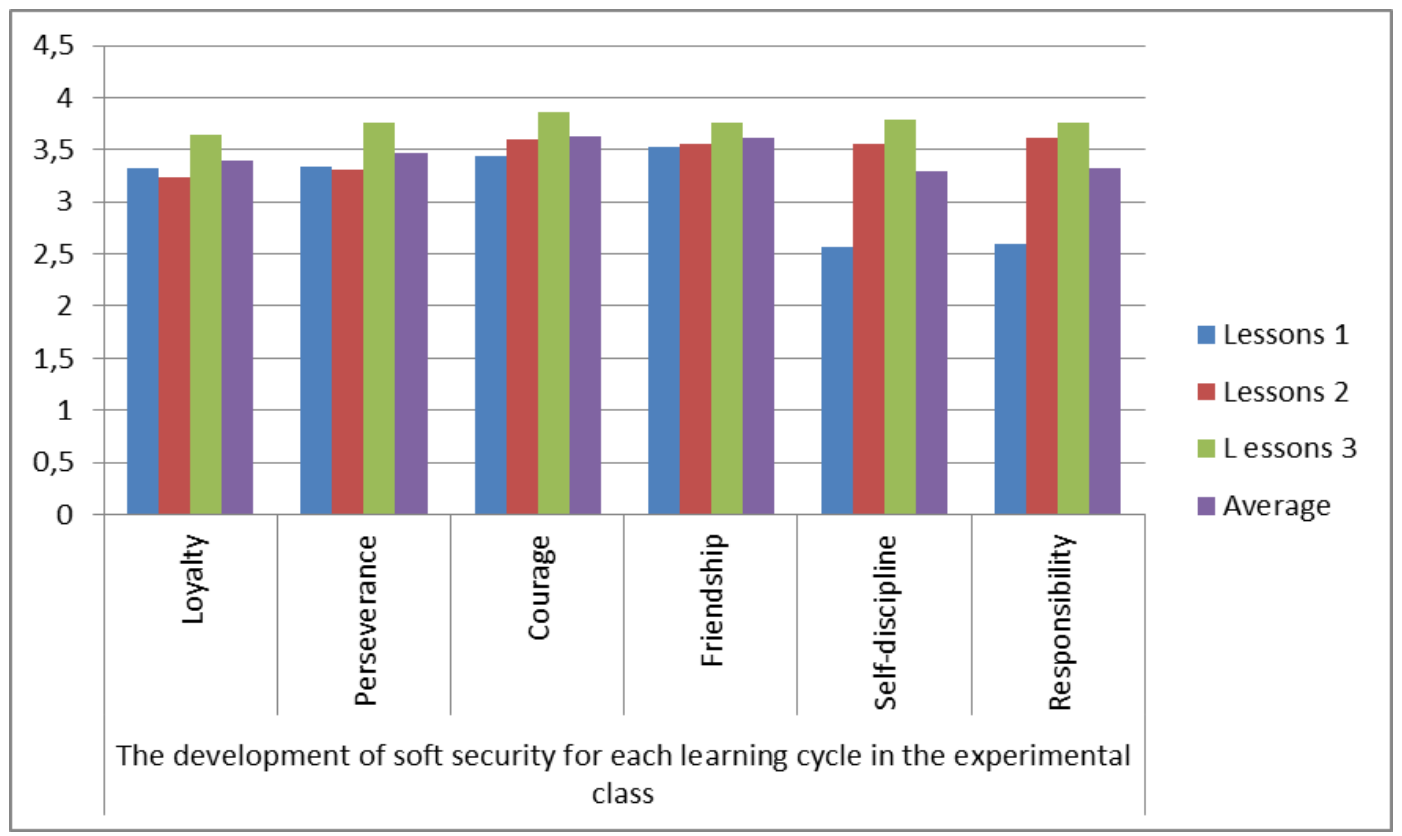

Figure 5. Graph of the development of soft security for each learning cycle in the experimental class 


\subsection{Assessment on Concept Understanding}

The direct impact from the application of SSP science learning that integrates the utilization of Indonesian megabiodiversity and nationalism character is on concepts understanding improvement. The data for concept understanding were collected through pre-test and post-test results. The purpose of these two types of tests is to know the gap due to the treatment results for each class and between the two classes, the experimental and control class, either in the schools of Atambua or
Entikong area. The type of test in the pre-test and post-test was in the form of description test related to the material of Natural Science. The description test contained 25 multiple choice items and 5 description questions that were used as indicators in measuring the knowledge of science concepts in the control class involving 56 students (29 students in Atambua and 27 from Entikong) and 51 students (26 students in Atambua and 25 students in Entikong) for the experimental class. The understanding concept test results are summarized in Table 6

Table 6. Summary of understanding concept test results

\begin{tabular}{lcccc}
\hline \multirow{2}{*}{\multicolumn{1}{c}{ Explanation }} & \multicolumn{4}{c}{ Test results of understanding concept } \\
\cline { 2 - 5 } & \multicolumn{2}{c}{ Control Class } & Eksperiment Class \\
\cline { 2 - 5 } & Pre-test & Post-test & Pre-test & Post-test \\
\hline Highest Score & 38 & 76 & 36 & 83 \\
\hline Lowest Score & 25 & 36 & 27 & 71 \\
\hline Mean Score & 30,25 & 46,75 & 31,5 & 78,25 \\
\hline Total of PD above KKM $(>75)$ & 0 & 2 & 2 & 40 \\
\hline Total of PD below KKM $(<75)$ & 56 & 54 & 49 & 11 \\
\hline Gain Average & \multicolumn{5}{c}{0.25} & & 0.68 \\
\hline
\end{tabular}

Table 6 shows the gap score of the test results from two classes. For the control class, the highest score in the pre-test was 38 and the lowest was 25. The average acquisition score of the control class for the time of the pre-test was 36 in which the none students who obtained the score above passing grade (> 75) and the score below the passing grade was 56 students. In the post-test control class, the highest score reached 76 and the lowest was 36 . The mean score of the control class in the post-test was 46.75 with the number of students above the passing grade (> 75) was 2 people and less than passing grade was 54 people. Based on the score of pre-test and the post-test, the control class gain average was 0.25 . It means that the control class standard gain was in the "low" category.

In addition, the table above indicates that the highest pre-test score in the experimental class was 36 while the highest post-test was 83 . The mean score of experimental pre-test was 31.5 with the students score (> 75) was 2 people. Meanwhile the post-test mean score of the experimental class was 78.5 with the number of students above the passing grade was 40 people. The mean gain standard in the experimental class was 0.68 or categorized into "moderate". According to this results, it can be concluded that the average of test result on the concept understanding from experimental class is higher, both the mean score and the standard gain average.

\section{CONCLUSION}

Based on the reserach on soft security development through SSP science learning integrating Indonesian megabiodiversity utilization with nationalism, some conclusions can be drawn, as follow, (1) The SSP model has been produced by utilizing Indonesian megabiodiversity and nationalism values that are feasible to be applied for the students junior high schools, (2) The application of subject specific pedagogic of science learning that integrates the utilization of Indonesian biodiversity and nationalism character has proven effective in enhancing students' soft security among the students of junior high schools in the border region, (3) The application of subject specific pedagogic science learning that integrates the utilization of Indonesian megabiodiversity and the nationalism character has proven effective in improving the concepts understanding of Natural Science course. 


\section{REFERENCE}

Akker, J.V. (1999). Principles and Methods of Development Research. In J. vam den Akker,R Branch,K Gustafson, N Nieveen and Tj.Plomp (Eds). Design Approaches and Tools in Education and Training (hlm. 1-14). Dodrecht : Kluwer Academic Publisher.

Banks, J.A. (1995). Transformative Challenges to the Social Sciences Disciplines: Implications for Social Studies Teaching and Learning.. Theory and Research in Social Education, XXIII(1), 220.

Bennett, William J. (Ed., 1997). The Book of Virtues for Young People: A Treasury of Great Moral Stories. New York: Simon \& Schuster.

Benninga, J. (1991). Moral Character and Civic Education in the Elementary School. Niership: Teachers College Press.

Dantes, N. (2012). Pendidikan Multikultur dan Integritas Kebangsaan dalam Pembelajaran PKn dan IPS (Makalah). Program Pasca Sarjana Undiksha. Singaraja: Undiksha.

Dantes, N. (2009). Pendidikan Teknohumanistik (Suatu Rangkaian Perspektif Dan Kebijakan Pendidikan Menghadapi Tantangan Global) (Makalah). Universitas Pendidikan Ganesha: Panitia Konaspi

Delors, J. (1996). Learning: The Treasure Within. France: UNESCO Publishing.

Delors, J. et al. (1996). Learning the Treasure Within, Education for the 21th Century.New York: UNESCO.

Departemen Pendidikan Nasional Republik Indonesia. Undang-undang Republik Indonesia Nomor 20 Tahun 2003 Tentang Sistem Pendidikan Nasional. Jakarta. 2003.

Departemen Pendidikan Nasional Republik Indonesia. Peraturan Pemerintah Republik Indonesia Nomor 19 tahun 2005 Tentang Standar Nasional Pendidikan. Jakarta. 2005.

Departemen Pendidikan Nasional Republik Indonesia. Undang-undang Republik Indonesia Nomor 14 Tahun 2005 Tentang Guru dan Dosen. Jakarta. 2005.
Lasley, T.J. (1996). Teaching Selflessness in A Selfish Society. Ohio State University: Phi Delta Kappa.

Lasmawan, Wayan (2015). Pengembangan Modul Belajar IPS Terintegrasi Berwawasan Local Genius untuk siswa SMP di Kabupaten Buleleng. Laporan Penelitian. Singaraja. Lembaga Penelitian Undiksha.

Lasmawan, Wayan (2014). Rekonstruksi Ontologi, Aksiologi, dan Epistemologi Pendidikan IPS Sekolah Dasar: Pengembangan Model Kurikulum Alternatif Berbasis Teori Rekonstruksi Sosial Ala Vygotsky. Laporan Penelitian. Singaraja. Lembaga Penelitian Undiksha.

Lasmawan, Wayan (2013). Pengembangan Pendidikan Multikultur: Revitalisasi NilaiKebangsaan dalam Konteks Instruksional. Laporan Penelitian. Singaraja. Lembaga Penelitian Undiksha.

Lasmawan, Wayan (2012). Pengembangan materi dan model pendidikan karakter bagi siswa sekolah dasar di Provinsi Bali. Laporan Penelitian. Singaraja. Lembaga Penelitian Undiksha.

Lasmawan, Wayan (2010). Pengembangan Spektrum Pendidikan IPS: Rekonstruksi Kompetensi Ke-IPS-an Berdasarkan Formula Rekonstruksi Sosial Vygotsky untuk Memfungsionalkan Kurikulum Tingkat Satuan Pendidikan IPS - SMP. Laporan Penelitian. Singaraja. Lembaga Penelitian Undiksha. 34

Lasmawan, Wayan (2010). Membangun Karakter Kebangsaan dalam Perspektif Budaya Lokal (Makalah). Disampaikan dalam Seminar Peringatan Hari Guru di Yayasan TP 45 Bali. Singaraja: Program Pascasarjana Undiksha.

Lasmawan, Wayan (2009). Studi evaluatif kinerja pelaksana pendidikan di era manajemen berbasis sekolah pada wilayah garapan UPT Kecamatan Tejakula - Kabupaten Buleleng. Laporan Penelitian. Singaraja. Lembaga Penelitian Undiksha.

Lickona, T. (1996). Eleven Principles of Effective Character Education. Journal of Moral Education.1, 1996, pp.93-94.

Plomp. (1999). Development Research in/on Education and Training. Netherlands: Twente University. 
Plomp. (2001). Development Research in/on Education Development. Makalah disajikan pada Seminar Nasional Pendidikan Matematika Realistik Indonesia. di USMP. Yogyakarta: 1415 November.
Sommers, Ch. H. (1993). Teaching The Virtues: A Blueprint for Moral Education. Chicago Tribune Magazine, September 12, 1993 